УДК 78.03:785.74-048.23(477)

DOI: $10.31318 / 2414-052 X .2(51) .2021 .239387$

НАТАЛІЯ ФЕЩАК

ORCID iD: 0000-0001-6543-1985

кандидат мистецтвознавства,

доцент кафедри струнно-смичкових інструментів Національної музичної академії Украӥни ім. П. І. Чайковського (Київ, Україна) feshchak.natalia@gmail.com

\title{
ВИКОНАВСЬКІ ЗАСАДИ ФУНКЦІОНУВАННЯ УКРАЇНСЬКОГО СТРУННОГО КВАРТЕТУ: ІСТОРИЧНИЙ АСПЕКТ
}

Розглянуто проблематику квартетного виконавства як окремої галузі музичної творчості. Визначено основні етапи розвитку камерно-інструментального виконавства в Європі, щзо мали характерний вплив на особливості становлення жанру струнного квартету в Україні. Зазначено, щуо рівноправний ансамбль чотирьох струнних інструментів, тембри яких наближені до людських голосів, формується як самостійний камерно-інструментальний ансамбль з другої половини XVIII століття в основному на рівні аматорського музикування. Висвітлено історичні зв'язки та культурно-естетичні контексти становлення украйнського струнного квартету. Підкреслено, шуо в Украӥні у камерному музикуванні XVIII-XIX століть набула поширення нова форма концертного «спілкування» - салонна музика. Наведено ряд відомостей, які сприяють повному розумінню означеного феномену. Відмічено, щяо салонна музика популяризувала як квартетні твори західних авторів, так і фольклорні обробки, знакові для української ансамблевої музики того часу. У кіниі ХІХ століття простежено очевидне зростання ролі професійного чинника у конщертній діяльності квартетів, а також збагачення й ускладнення стилю квартетного письма. Доведено, що аматорське музикування починає поступово втрачати свій пріоритет. Зазначено, у XX столітті в Украӥні формується нова школа украӥнського квартетного виконавства, позначена високою професійною майстерністю, своєрідною манерою гри. Зосереджено увагу на розвитку квартетного жанру у Києві, Львові, Одесі, Харкові, де створюються професійні квартетні ансамблі з числа найкращих музикантів того часу. Відмічено, щзо великим поштовхом для розвитку українського квартетного виконавства XX століття стало відкриття вищих музичних навчальних закладів, де була започаткована навчальна дисципліна «Квартетний клас». Охарактеризовано основні тенденції розвитку українського струнного квартету в кіниі ХХ століття, визначено два основних напрями - академічний та салонний. Вказано на низку факторів, щзо спричинили такий культурний феномен. Доведено факт актуалізації розвитку жанру струнного квартету в Украӥні на початку ХХІ століття.

Ключові слова: украӥнський струнний квартет, концертна діяльність, виконавство, камерне музикування, салонність.

Постановка проблеми... В останню третину XX століття спостерігається активне відродження жанру вітчизняного струнного квартету. Особливо, це стає помітним у салонному музикуванні; створюються десятки квартетних

\footnotetext{
(Фещак Н., 2021
} 
колективів для музичного оформлення різноманітних свят, корпоративів тощо. Напрям розвитку квартетного мистецтва починає різко змінюватись наприкінці першого десятиріччя третього тисячоліття, коли, попри економічну та політичну кризу в суспільстві, пожвавлюється академічний фестивальний рух. Струнний квартет стає бажаним учасником класичних фестивалів, філармонійних концертів, презентацій та офіційних заходів. При цьому урівноважується потреба у камерному висловлюванні, гармонійному взаємопроникненні виконавських традицій академічного і салонного квартетних жанрів. Саме тому актуальною постає проблема історичного i культурологічного аналізу квартетного феномену, як одного 3 найбільш змістовних і презентабельних розділів камерної музики.

Аналіз останніх досліджень і публікацій... Попри значну кількість досліджень 3 проблематики квартетного виконавства (наукові роботи О. Андріанової, М. Боровика, Н. Дикої, І. Польської, Л. Раабена, Г. Фельгуна, Б.Харитонова та ін.) у вітчизняному музикознавстві відсутні спеціальні роботи, скеровані на висвітлення даної теми в цілому. Проблема напрямів розвитку квартетного виконавства на сучасному етапі постає важливою галуззю пошуків вітчизняного музикознавства, історіографії, культурології. Її дослідники фокусують увагу на таких проблемних «зонах», як:

- загальні аспекти співвідношення «академічних» та «салонних» форм музикування на сучасному етапі (Адріанова, 2006; Дика, 2004; Сумарокова, 2003);

- історико-культурологічний аспект розвитку квартетного музикування в Україні (Кияновська, 2000;. Корній, 2001; Щепакін, 2012);

- генеза української квартетної музики у ХХ столітті (Давидян, 1984;. Дика, 2004);

- диференціація жанру, творчість квартетних виконавців - перекладення, обробки, аранжування, оригінальні твори, створення музичної образності певного типу, пов’язаного з відео- та перформансним відтворенням (Загайкевич, 1982; Калениченко, 1990; Сікорська (1994). 
Щодо освітнього аспекту професійного квартетного мистецтва, а саме, відкриття у вищих музичних навчальних закладах класів квартету, відзначимо важливість роботи регіональних музично-освітніх установ, які зберігають i поширюють інформацію щодо концертних традицій європейського музикування.

Мета дослідження: визначити специфіку історичних зв'язків та культурно-естетичних контекстів становлення струнного квартету в Україні 3 розглядом виконавського аспекту розвитку даного жанру, як у академічному, так і у салонному напрямах.

\section{Завдання дослідження:}

1) виявити місце квартетного жанру у складній системі камерної музики;

2) диференціювати поняття «академічного» та «салонного» квартетного музикування;

3) систематизувати історичні особливості становлення квартетних жанрів академічного та салонного напряму;

4) докладно розглянути регіональні особливості становлення академічного та салонного квартетного виконавства;

5) визначити перспективи розвитку квартетного виконавства.

Виклад основного матеріалу дослідження... Історичний аспект появи європейської традиції камерно-інструментального музикування в Україні сягає ще XVII століття, коли виконавське мистецтво було представлене театрами та капелами поміщицьких маєтків, князівських палаців, хоровою та вокальноансамблевою традицією братських шкіл та монастирів. Мода на «домашню» музику спонукала до розвитку універсального музично-прикладного виду виконавського мистецтва: так, князівські двори Київської Русі за прикладом візантійських імператорів наймали співаків, музикантів, танцюристів (відомо, що скоморохи виступали при дворах російських царів ще до 1648 року). 3 появою у другій половині XVII століття придворних театрів, оркестрів починається справжній розвиток камерної музики, зокрема квартетної.

У Києві вже з XVIII століття у багатьох будинках збиралися різного типу 
камерні ансамблі, в тому числі й квартети. Разом 3 місцевими аматорами виступали такі прославлені європейські віртуози як А. Контський, Ф. Серве, С. Шіффе. Першим відомим професійним квартетом 3 постійним складом учасників у Росії, був ансамбль у який входили Ф. Тіц (перша скрипка), Робе або О. Тевес (друга скрипка), Штокфіш (альт) та А. Дельфіно (віолончель). Цей прекрасний колектив у 1790-х роках захоплював сучасників своїми виступами на придворних концертах. За свідченнями сучасників, окрасою концертів був Ф. Тіц - «... ніщо не могло зрівнятися 3 приємністю його смичка, 3 тими дивними, ніжними звуками, які злітали з його струн» (Давидян, 1984, с. 5).

Значну роль у розвитку квартетного виконавства не тільки Свропи, але й України, відіграла музична діяльність графа Андрія Розумовського. Отримавши гарну освіту, у 25-річному віці А. Розумовський був направлений імператрицею Єлизаветою на дипломатичну роботу у Відень. Музичні вечори були практикою життя Відня, а Розумовський - їх постійним активним учасником. Російська аристократія у Відні захоплювалась новою музикою, концертні салони віденської аристократії були завжди переповнені шанувальниками музичного мистецтва і могли стати місцем вірогідної зустрічі різних видатних особистостей. Також «концерти за участю струнних квартетів регулярно відбувалися в будинку бригадира російської військової місії графа I. Ю. БроунаКамуса» (Ільченко, 1996, с. 4).

Після смерті батька у 1803 році, отримавши спадщину, граф Андрій Розумовський охоче організовує найкращий квартет свого часу i, по суті, перший у Європі квартетний ансамбль постійного складу - у ньому грали І. Шуппанціг, Ф. Вайс, Дж. Лінке, партію другої скрипки виконував сам граф. Інформації про квартет Розумовського нечисленні, але відомо, що у 1813 р. ансамбль збирався виступати з концертами в Бадені та політична ситуація в Свропі склалася таким чином, що Розумовський змушений був відмінити поїздку. Після повернення графа у Росію ансамбль виступає в іншому складі. 3 концертами квартет об’іздив багато міст Російської імперії, також неодноразово музиканти гастролювали і в Києві. 
На початку XIX століття аматорське квартетне музикування в Європі починає поступово втрачати своє суспільне значення. Шанувальники музичного мистецтва були незадоволені творчістю деяких композиторів, які писали тільки для віртуозів високого гатунку. Тому одні аматорські квартети намагалися впоратися 3 непереборними для них труднощами, інші зверталися до творів невисокого технічного рівня. Все це, безсумнівно, вказує на ознаки деградації аматорського мистецтва, яке починає відходити в минуле разом з палацовоаристократичними формами концертного життя. Прогресивним $\epsilon$ те, що внаслідок складнощів розвитку жанру, деякі квартетні ансамблі продовжували концертувати, виконуючи на концертах навіть власні твори.

У цей же час у камерному музикуванні Східної Свропи набуває поширення специфічна форма музичного спілкування, так звана «камерна салонна музика», яка передбачала музичний супровід у домашньому колі, що об’єднував родичів, друзів, однодумців. Таке мистецтво мало на меті відвернути людину від повсягденних стресів, вплинути на гармонійність їі світосприйняття. Крім того, воно передбачало естетизацію домашнього побуту, що пов'язувався не тільки зі слуханням музики, але й із участю у музикуванні. Саме у квартетному виконавстві поступово викристалізувалася ідея висловити «живими» музичними засобами найбільш інтимні почуття у формі «довірчої бесіди».

Розходження музикознавчих уявлень про цінність та природу салонності,

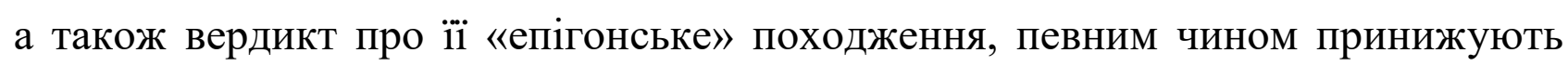
значення цього, на наш погляд, значного музичного доробку, який слугував своєрідним «містком» між культурами Західної та Східної Європи, між ментальностями різних прошарків населення, між класичними зразками романтизму та його подальшими різновидами, що мали місце також у $\mathrm{XX}$ столітті.

У дослідженні О. Андріанової «Салонна музика як складова частина російського романтизму» подається визначення салонної музики як самостійної системи камерних жанрів, що виникла на межі XVIII-XIX століть, 3 наявністю відповідної змістовної сфери та власними засобами виразності; у вузькому сенсі 
— це сукупність невеликих музичних творів із полегшеною фактурою, призначених для домашнього музикування виконавцями «... 3 непрофесійним рівнем музичної освіти та володінням яким-небудь музичним інструментом, а також розраховані в основному на непідготовленого слухача» (Андріанова, 2006, c. 42$)$.

Проте, таке розуміння є дещо спрощеною спробою ототожнення термінів «салонна» та «камерна» музика. Посилаючись на історичні особливості розвитку російського романтизму, авторка відзначає прогресивний характер тенденції салонного музикування: «... популярність салонного музикування сприяє тому, що навчання дітей музиці, обов'язкове в аристократичному середовищі, стало невід'ємною частиною освіти і у дворянському середовищі, i в сім'ях духовенства» (Андріанова, 2006, с. 42).

Характерною особливістю салонної музики Росії ХІХ століття є взаємодія російського та українського мелосу 3 європейськими інтонаціями (італійська оперна кантилена, сентиментальний французький романс, німецький зінгшпіль). Таким чином, створювалися «прикладні» жанри, прокладалися шляхи до виникнення нових, демократичних зразків музики, що базувалися на синтезі мистецтв, і у будь-яку епоху музичної історії мали перехідне значення. Як правило, такі твори включали компоненти популярного візуального мистецтва та театральності, що для музики камерних жанрів давало нові витоки інтерпретаційних можливостей. Спрощення музичної ідеї, i, водночас, ускладнення виконавських виразових засобів, - ось процеси, які супроводжували напрямок салонної музики і формували подальші перспективи розвитку музичного мистецтва.

Зокрема, на нашу думку, салонність $є$ природною формою саме квартетного музикування, завдяки обмеженому ансамблевому складу — формою творчого спілкування, дійсної художньої «співпраці» між музикантами, i, певним чином, творчою лабораторією, яка дозволяє уточнювати художні критерії квартетного виконавства, активно оновлювати репертуар, постійно працювати над сценічною довершеністю концертних виступів, що, безумовно, 
сприяє прогресу виконавського мистецтва в цілому.

Жанр струнного квартету ніс у собі певну соціальну функцію. У мистецтві салонної музики епохи Просвітництва, він став, до деякої міри, віддзеркаленням процесу демократизації суспільних відносин. Але це аж ніяк не означало будьякого спрощення у розвитку музичного мистецтва. Навпаки, струнний квартет втілив в собі абсолютно нові форми, удосконалюючи природну завершеність i красу гармонійного чотириголосся. Саме тут була досягнута своєрідна витонченість, пластичність і художня змістовність голосоведення, яку Стендаль вважав «... бесідою чотирьох розумних людей» (Ступель, 1970, с. 109).

Українська салонна музика — явище загальнокультурного значення, яке похідне від тенденцій, відзначених музикознавцями у Росії та Західній Європі. На початку XIX століття традиційними осередками музичного життя України залишалися поміщицькі маєтки. Відомий оркестр, а при ньому і квартет, мав у своєму маєтку О. Будлянський в с. Чемері на Київщині, квартетні зібрання, що постійно утворювалися І. Лизогубом у Седневі-Чернігові, Г. Данилевським, М. Ясінським-Дорошенко у Києві є відомими прикладами захоплення цим мистецтвом. Крім квартетів, були поширені й інші струнно-смичкові ансамблі (тріо, квінтети, секстети). Домашнім музикуванням особливо славилася Полтавщина; там функціонувало на той час приблизно 35 оркестрів (Шамаєва, 1996).

У Західній Україні головним культурним центром було місто Львів. Досдідниця Л. Кияновська розглядає діяльність галицького салону, який посів помітне місце у культурно-мистецькому житті краю (2000). На розвиток струнного квартету в цьому регіоні вплинув відомий скрипаль Кароль Ліпінський. Саме у Львові він виступав зі своїми першими сольними концертами, а також як квартетист у ансамблі 3 Мазасом, Шупанцігом, Кремезом. На початку 1820 року К. Ліпінський організував симфонічний оркестр, який улітку виступав з концертами на контрактових ярмарках у Києві, у 1824-1825 роках організовував щотижневі абонементи квартетних вечорів. Ліпінський неодноразово виступав у Кам’янець-Подільському, Кременці, Дубно, 
Одесі, належав до найбільш бажаних і гаряче очікуваних гастролерів.

Музичне життя Києва на початку XIX століття розвивалося нерівно й бурхливо. Його піднесення і спади визначалися соціально-економічними причинами, політичними обставинами. До найважливіших осередків мистецького життя належали контрактові ярмарки. Ці торгові з'їзди переведені сюди з Дубно у 1797 році і з того часу регулярно відбувалися на Подолі, викликаючи величезне пожвавлення серед населення міста. Особливо важливу роль відігравав контрактовий ярмарок в активізації концертного життя міста. Адже ті, що приїжджали до Києва, прагнули окрім улагодження різних справ розважитися, набути мистецьких вражень. Під час укладення контрактів щовечора відбувалися концерти, в яких брали участь видатні артисти - виконавці з Свропи: Ф. Ліст, К. Ліпінський, Б. Ромберг, Г. Венявський та інші (Загайкевич, 1982).

Салонні вечори в Одесі часто влаштовував граф Воронцов. У 20-х роках XIX століття він мав квартет аматорів, у якому виступав талановитий віолончеліст О. Сухов. Після квартетного концерту у 1823 році музикант Ланжеров вказував на те, що йому запам'ятався квартет російських музикантів, які належать графу Воронцову, оскільки музиканти добре грають твори не тільки Моцарта і Гайдна, а й інших композиторів (Давидян, 1984). Мода на квартети стала настільки велика, що захопила і Одесу. В багатьох приватних будинках було створено квартети, в яких охоче брали участь знатні міщани. До кінця XIX століття аматорське музикування починає поступово втрачати своє значення.

Становлення квартетного стилю виконання йшло одночасно з розвитком музики цього жанру, збагачуванням і ускладненням стилю квартетного письма. У цей час в Україні простежується істотне пожвавлення музичного життя, зокрема концертної діяльності. У Наддніпрянській Україні діяли російські музичні осередки, а на заході країни - австрійські та польські. «Імперська політика національного гноблення, яку проводила чужоземна влада в обох частинах України, призвела до різних труднощів у виконанні української музики. Влада вела цілеспрямовану політику на звуження функціонування української 
музики в суспільстві» (Корній, 2010, с. 298).

Камерно-інструментальному мистецтву України XIX століття притаманні типові риси західноєвропейському романтизму, воно набуло професійних якостей саме в домашньому, маєтковому музикуванню. 3 об'єктивних обставин українська інструментальна музика, порівняно 3 європейською, була зорієнтована, в основному, на західну музику. В активізації концертного життя в Україні значну роль відіграли відділення Імператорського Російського музичного товариства (IPMT), які, за сприяння влади, розвинули музичнопросвітницьку діяльність. Основною метою товариства був розвиток російського музичного мистецтва, були організовані концерти, конкурси на краще виконання творів. Музичні відділення відкрилися у різних містах України: Києві, Харкові, Одесі, Полтаві, Миколаєві, Катеринославі, Херсоні.

Ознайомлення українських слухачів із західною та російською музикою мало важливе значення для розвитку камерного (квартетного) жанру. До репертуару квартетних зібрань входили, з одного боку твори Гайдна, Моцарта, Бетховена, Шуберта, Шумана; з іншого — різноманітні перекладення оперної чи симфонічної музики, обробки народних мелодій.

Музичному вихованню особливе місце відводилось у Харкові, де у 1805 р. відкривається Харківський університет. «Тут учні музичних класів навчалися гри на фортепіано та струнних інструментах у прекрасних викладачів I. Лозинського, В. Андрєєва, Ф. Шульца. Крім гри в оркестрі учні музикували і в квартеті» (Корній, 2001, с. 298). С відомості, що «... у першій половині XIX століття у Харкові кілька років існував квартет організований князем М. Голіциним» (Калениченко, 1990, с. 265).

У 1871 р. перший сезон квартетних зібрань Харківського відділення IPMT почався з виступів ансамблю в складі: Шпора, Гельмиха, Шульца, Ене. Цікаво відзначити, що в різний час учасниками Одеського квартету були відомі чеські музиканти - скрипаль Я. Коціан і віолончеліст Л. Зеленка, які стали потім артистами «Чеського квартету». Постійного квартету при відділенні не було, у ньому періодично брали участь музиканти Й. Шадек, Ф. Шадек, І. Водольський, 
А. Гене, Р. Пфеніг, Ф. Віленський, К. Пятигорович, М. Поляничевський, В. Мешков та інші (Давидян, 1984). У квартетних вечорах брали участь і гастролери - скрипаль Г. Венявський, віолончеліст А. Портен, піаніст П. Шлецер. У майбутньому відбуваються характерні для більшості периферійних квартетів багаторазові зміни учасників, на деякий час вони припинились тільки з встановленням у 1883 році нового складу - А. Пестеля, С. Дочевського, Алексеєнко, А Глена.

1867 рік виявився благодатним для Одеси в контексті впровадження камерних виконавських традицій. Адже саме з оселенням у цьому році в Одесі скрипалів М. Франка, К. Бабушки та віолончеліста М.Куммера камерна музика в місті вийшла 3 приватних салонів на велику концертну естраду. Восени цього року «Одеський вісник» анансував серію квартетних зібрань, які відбувались в залі німецького клубу «Гармонія» за участю Франка, Бабушки, Россета, Кумера. 3 того часу протягом наступних трьох років квартетні концерти в Одесі були регулярними та бажаними культурними подіями (Щепакін, 2012).

До початку XX ст. в Російській імперії (й на українських землях у ії̈ складі) нараховувалось 33 відділення IPMT, в кожному з них були квартетні ансамблі. Поряд з прекрасними квартетами «столичного рівня» були середні та слабкі за якістю виконання ансамблі, де разом 3 професіоналами грали музикантиаматори. Проте, важливо відзначити й їхній внесок у розвиток квартетного мистецтва.

Поряд з активізацією композиторської уваги до квартетної творчості, у XX столітті набирає бурхливого розквіту українське квартетне виконавство, що починає здобувати рівень міжнародного визнання. Великого поштовху для подальшого його розвитку надало відкриття в Україні середніх та вищих музичних учбових закладів, консерваторій (початок XX століття), де спочатку клас ансамблю виконував швидше додаткову функцію до основної спеціалізації «Концертний виконавець». I тільки в повоєнний час, у 50-60-і роки XX століття, у навчальних закладах почали формуватися кафедри камерного ансамблю (здебільшого класи квартету у їх складі). Практика навчання музикантів 
показала, що вміння грати в ансамблі не тільки прищеплює необхідні професійні навички, розширює світогляд, але й виявляється для багатьох основною спеціальністю, тому що камерна музика стає в сучасному житті усе більш затребуваною і виконуваною.

Витоки створення навчальної дисципліни «Квартетний клас» в Київській державній консерваторії (нині Національна музична академія України ім. П. І. Чайковського) сягають 20 -х років XX ст. Першими викладачами класу квартету в консерваторії стають Н. Скоморовський, Д. Бертьє, С. Вільконський, які були не тільки чудовими солістами, а й блискучими ансамблістами. 3 часу відкриття Київської консерваторії формуються струнні квартети з числа викладачів консерваторії. У 1913-1914 роках тут активно функціонують квартети у складі: Ф. фон Мулерт, С. Риб, С. Каспін, М. Урденко; у 50-ті роки - Б. Фішман, О. Старосельський, Г. Пеккер; у 60-ті - П. Макаренко, В. Стеценко, 3. Дашак, В. Червов; 70-ті роки - О. Криса, О. Кравчук, А. Венжега, В. Потапов. Концерти за їх участю долучали студентську молодь до кращих зразків світової музичної класики та до творів сучасних композиторів.

У 1946 році квартетний клас відокремлюється від кафедри камерного ансамблю; як окрема секція входить до кафедри струнно-смичкових інструментів.

У різні часи струнний квартет викладають прекрасні музиканти: О. Старосельський, П. Макаренко, О. Кравчук, Р. Гураль, Л. Краснощок, В. Гайдук, Л. Бильчинський, В. Боровик, Ж. Ляшенко та ін.

3 відкриттям у 1903 році у Львові Вищого музичного інституту ім. М. В. Лисенка (тепер Львівська національна музична академія імені М. В. Лисенка) починається розквіт українського професійного музичного виконавства (зокрема ансамблевого). В 1911-1912 роках дирекція інституту ввела в навчальні плани курси «вправ у збірній музиці для всіх учеників» (очевидно, основ ансамблевої гри). Як директор навчального закладу С. Людкевич у 1912 р. започатковує нову форму концертно-виконавської діяльності педагогів та учнів — вечори класичної та камерної музики. 3 
концертами камерно-інструментальної музики почали виступати Є. Щедрович-

Ганкевич, Р.Придаткевич та його учень Є. Перфецький (скрипка), Б. Бережницький, А. Вольфсталь (віолончель).

У Львівській консерваторії ім. М. Лисенка до 1972-го року квартетний клас відносився до оркестрової кафедри (перші викладачі - П. Пшеничка, П. Макаренко). У 1972 році за ініціативою ректора консерваторії, професора 3. Дашака клас струнного квартету приєднано до кафедри камерного ансамблю.

В Одеській консерваторії ім. А. В. Нежданової (тепер Одеська національна музична академія) камерна музика звучала з дня ії заснування. У повоєнні часи камерно-ансамбливе музикування було стилем роботи консерваторії, особливо в 1960-ї роки — роки ректорства В. Повзуна. Педагогічний струнний квартет найяскравіших музикантів - В. Проніна, О. Зіссермана, М. Грінберга, О. Гуменюка — радував публіку вечорами камерної квартетної музики. Зі струнним квартетом часто концертував сам В. Повзун (кларнет). Розквіт камерного виконавства дав підставу у 1968році створити кафедру камерного ансамблю й квартету. Її засновник - заслужений діяч мистецтв, професор В. Повзун. Формування класу струнного квартету на кафедрі пов’язують із ім’ям талановитого альтиста, випусника Г. Майя - О. П. Шкарпітного. У різні роки у квартетному класі викладали П. Купін, С. Шольц, Л. Лембергський, Б. Мордкович, М. Грінберг, А. Вайнер, тепер - О. Базан, М. Курочкіна.

Квартетна музика в Одесі звучала завжди, а в ХХ ст. розвиток цього жанру тут був дуже стрімким. Можна стверджувати, що в Одесі квартетне виконавство створило свою «автономну» музичну нішу. Учні Школи ім. П. Столярського, скрипалі В. Н. Пронін і А. Л. Зісерман, у 1946 році разом 3 А. Я. Гуменіком (віолончель) і М. М. Грінбергом (альт) створили струнний квартет, який більше 35 років був гордістю консерваторії. (Корній, 2001).

На початку XX століття кожен культурний центр України мав струнний квартет: поряд 3 Києвом, Львовом, Одесою та Харковом - Житомир, Катеринослав (тепер Дніпро ), Миколаїв, Полтава та інші міста.

У 20-х роках ХХ століття в Україні формується нова школа українського 
квартетного виконавства, позначена високою професійною майстерністю, своєрідною манерою гри — створено у 1919 році (за ініціативою композитора Я. Степового) перший Державний квартет УРСР, Струнний квартет ім. М. Леонтовича у Харкові (1925), Київський квартет (1926), Квартет ім. П. Чайковського у Києві (1924), які тісно пов’язали свою діяльність 3 сучасною українською творчою практикою. Ці колективи, як і інші квартети того часу, виступали у клубах, підприємствах, установах, гастролювали по містах України. Значну діяльність проводив також Квартет ім. Ж. Вільйома (організований у 1920 р.).

У Харківському державного інституту мистецтв ім. І. Котляревського (тепер Харківський національний університет мистецтв ім. І. Котляревського) в 1964 році створено самостійну кафедру інструментального ансамблю. На початку 1968 року до кафедри включено клас струнного квартету. Для роботи викладачами запрошуються Й. Гельфандбейн, І. Сиротін. Започаткування так званих «квартетних вечорів» пов’язано з ім'ям Фелікса Спартака-Карловича Щелкановцева. Він умів захопити студентів музикуванням у струнному квартеті. Сам із задоволенням грав зі студентами на квартетних вечорах. Студентські квартети його класу були гідно представленні на VII та IX конкурсах ім. С. Прокоф`єва, де на обох одержали третю премію.

Квартетне виконавство харківщини відзначалось інтенсивністю і розмаїтістю. Серед філармонійних колективів 70-х років одне з чільних місць, поряд з лисенківцями, посів організований у 1971 році Київський квартет ім. М. Леонтовича. Впродовж творчого життя (1971-1991 роки) колектив цього квартету зазнав численних змін: С. Кобець (перша скрипка 1977-1991, а в 19711977 виконував партію другої скрипки); О. Панов (друга скрипка — 31977 по 1983); Ю. Харенко (друга скрипка — 31983 по 1991рp.); альтисти Г. Вайнштейн (1971-1980), В. Баранов (1980-1991), Б. Девятов (з 1991 року). Постійно в колективі працював лише віолончеліст Володимир Пантелєєв. У 90х роках учасники квартету виїхали на постійне місце проживання до США, але там колектив проіснував недовго і розпався. 
Серед численних камерно-інструментальних ансамблів харківського регіону 70-х років вирізнявся квартет, організований з числа професорськовикладацького складу та студентської молоді Харківського інституту мистецтв. Впродовж двох років (1976-1978) у стінах цього музичного вузу продуктивно працював квартет у складі: М. Пітельмана, Г. Купермана, В. Ковальчука, О. Панасяна.

Помітним мистецьким явищем 60-х років стала поява у Києві Квартету ім. М. Лисенка. «Цей квартет став спадкоємцем традицій знаного в столиці у 20-50х роках Квартету ім. Ж. Вільйома. Діяльність колективу, заснованого у 1951 році за ініціативою проф. Ю. Крихи, була надзвичайно вагомою. Перший склад квартету був такий: О. Кравчук (перша скрипка), А. Сікалов (друга скрипка), Р. Гураль (альт), Л. Краснощок (віолончель)» (Боровик, 1980, с. 16). Високий професіоналізм, рідкісна працездатність, творча ініціатива дозволили лисенківцям започаткувати грандіозні мистецькі акції, які не мали аналогів в історії українського квартетного виконавства.

Професійна досконалість колективу привернула увагу українських композиторів різних поколінь. Цикли концертів під рубрикою «Перше виконання» звучать на естрадах Будинку композитора, Колонного залу ім. М. Лисенка, Будинку органної та камерної музики. Майже всі квартетні прем’єри українських композиторів, зокрема Є. Станковича, Г. Ляшенка, Ю. Іщенка, М. Скорика, В. Сильвестрова, Л. Дичко, І. Карабиця, відбулися саме завдяки лисенківцям.

Квартет імені М. Лисенка (теперішній склад: А. Баженов (перша скрипка), О. Серединський (друга скрипка), С. Романський (альт), І. Кучер (віолончель)) — єдиний український державний струнний квартет, що понад 70 років активно пропагує твори зарубіжних та вітчизняних композиторів та вносить свій шарм у розвиток вітчизняного квартетного мистецтва.

У 30-ті роки створюється квартет 3 числа викладачів Львівської консерваторії у складі: Й. Цетнер (перша скрипка), А. Солтис (друга скрипка), A. Лобожинський (альт), П. Пшеничка (віолончель), який довгий час 
функціонував при Польському Музичному Товаристві. В післявоєнний період при консерваторії організувався квартет, до якого входили: І. Гольфельд, В. Стеценко, Н. Пархоменко, П. Пшеничка, репертуар якого грунтувався на творах західноєвропейських і вітчизняних авторів (Дика, 2004).

Суттєво пожвавила концертне життя Львова поява струнного квартету при Львівській консерваторії у складі: О. Деркач, В. Каськіва, 3. Дашака, Х. Колесси, дебют якого відбувся у грудні 1965 року. Майже всі мистецькі акції Львова відбувалися за активною участю квартету Львівської консерваторії - він був постійним учасником митецьких форумів: «Львівська золота осінь», «Віртуози країни», брав участь у міжнародному фестивалі «Віртуози» (Дика, 2004).

Активну концертну діяльність у Львові та інших містах західного регіону проводив квартет Львівської філармонії «Кантабіле», заснований у 1985 році. У 1995 році при Національній філармонії України з числа випускників Київської консерваторії ім. П. І. Чайковського створений струнний квартет «Каприс класик». У 2007 році створюється ансамбль нової генерації музичної України Струнний квартет «Колегіум» та інші професійні квартети.

На розвиток жанру неабиякий вплив мають проведення міжнародних конкурсі в Україні, а саме:

- Міжнародний інструментальний конкурс ім. Є. Станковича в м. Києві;

- Всеукраїнський конкурс камерних ансамблів ім. І. Я. Падеревського в м.Житомирі;

- Всеукраїнський конкурс камерних ансамблів і квартетів в м. Львові;

- Міжнародний конкурс камерних ансамблів ім. Д. Бортнянського в м. Києві;

- Національний конкурс камерних ансамблів ім. В. Повзуна у м. Одесі.

\section{Висновки.}

1. Починаючи з XVIII століття камерно-інструментальне виконавство в Україні носило аматорський характер, зокрема, форми «домашнього» або «салонного» музикування представляли основні типи музичної ансамблевої практики. 
2. На початку другої половини XIX століття в жанровій панорамі української музики спостерігається послідовний процес розвитку квартетного мистецтва, зумовлений такими чільними ознаками музичного романтизму як спрямування до сконцентрованості почуттів та камерності їх висловлювання. На зміну періоду салонного музикування приходить час яскравих концертних виконань, пов’язаних 3 діяльністю IPMT у Центральній і Східній Україні та польсько-австрійських осередків у Західній Україні.

3. Одночасно 3 активізацією композиторської уваги до квартетної творчості у XX столітті бурхливо розвивається квартетне виконавство. У першій половині XX століття створюються перші професійні українські струнні ансамблі, що здобувають міжнародні визнання. Великого поштовху для розвитку українського струнного квартету надало відкриття у вищих музичних учбових закладах кафедр камерного ансамблю, до складу яких входять класи квартету.

4. У кінці ХХ століття та до сьогодні провадиться концертна та конкурснофестивальна діяльність українських квартетів, що свідчить про подальші перспективи розвитку цього жанру. Паралельно 3 концертними виконавцями слід відмітити звернення музикантів академічної практики до гри в квартеті для салонного музикування, що $є$ також дієвим способом залучення широкої глядацької аудиторії та популяризації квартетної музики.

Перспективи подальших розвідок... У запропонованій статті було порушено лише один аспект формування квартетного мистецтва — історичнокультурологічний. Історію жанру простежено найбільш детально від початку зародження цього ансамблевого феномену камерного виконавства на Україні, а також, як форми салонного музикування. Саме тому перспективними напрямами подальших розвідок цієї проблеми є вивчення репертуару сучасного квартетного мистецтва та специфіки його інтерпретації.

\section{Список використаної літератури і джерел}

1. Андріанова, О., 2006. Салонна музика як складова частина російського романтизму. Украӥнське музикознавство Наџіональної музичної академії Украйни ім. П. I. Чайковського, 34, cc.40-47.

2. Боровик, М., 1980. Квартет ім. М. В. Лисенка. Київ: Музична Україна.

3. Давыдян, Р., 1984. Квартетное искусство. Проблемы исполнительства и педагогики. Москва: Музыка. 
4. Дика, Н., 2004. Квартетне виконавство України (60-80 роки ХХ століття), західний регіон. Мистецтвознавчі записки Державної Академії керівних кадрів культури і мистецтва, 5, cc.16-21.

5. Загайкевич, М., 1982. Музично-театральне життя України першої половини 19 століття. Київ музичний, сс.20-31.

6. Ільченко, Л., 1996. Граф Розумовський. Дзеркало тижня, 38, с.2.

7. Калениченко, А., 1990. Камерно-інструментальні ансамблі. У кн.: О. Пархоменко, ред. Історія української музики. Київ: АН УРСР; ІМФЕ ім. М. Т. Рильського, сс.265-286.

8. Кияновська, Л. О., 2000. Стильова еволюичія галицької музичної культури XIX-XX сm. Автореферат дис. д-ра мистецтва. Національна музична академія України ім. П. I. Чайковського.

9. Корній, Л., 1998. Історія украӥнської музики. Т. 2. Київ-Харків-Нью-Йорк: видавництво М. П. Коць.

10. Корній, Л., 2001. Історія украӥнськоӥ музики. Т. 3. Київ-Харків-Нью-Йорк: видавництво М. П. Коць.

11. Ступель, А., 1970. В мире камерной музыки. Ленинград: Музыка.

12. Сумарокова, В., 2003. Музичне виконавство як об'єкт дослідження. Мистецькі обрії 2001-2002: Альманах. Науково-теоретичні праці та публічистика, сс.212-222.

13. Фещак, Н., 2011. Салонність як фактор розвитку українського квартетного жанру. Вісник Державної Академії керівних кадрів культури і мистеитв, 4, сс.191-194.

14. Шамаєва, К., 1996. Музична освіта в Україні в першій половині 19 століття. Київ: Музична Україна.15. Щепакін, В., 2012. Камерне виконавство в Одесі наприкінці 1860-х початку 1870-х рр. як приклад творчої взаємодії представників різних культур. Культура України, сс.276-288.

\section{References}

1. Andrianova, O., 2006. Salonna muzyka yak skladova chastyna rosiiskoho romantyzmu [Salon music as an integral part of Russian romanticism]. Ukrainske muzykoznavstvo Natsionalnoi muzychnoi akademii Ukrainy imeni P. I. Chaikovskoho, 34, pp.40-47.

2. Borovyk, M., 1980. Kvartet im. Lysenka [M. V. Lysenko Quarter]. Kyiv: Muzychna Ukraina.

3. Davydyan, R., 1984. Kvartetnoe iskusstvo. Problemy ispolnitel'stva i pedagogiki [Quartet art. Problems of performance and pedagogy]. Moskva: Muzyka.

4. Dyka, N., 2004. Kvartetne vykonavstvo Ukrainy (60-80 roky XX stolittia), zahidnyi rehion [Quartet performance of Ukraine (60-80 years of the XX century), western region]. Mystetstvoznavchi zapysky Derzhavnoi Akademii kerivnykh kadriv kultury i mystetstva, 5, pp.16-21.

5. Zahaikevych, M., 1982. Muzychno-teatralne zhyttia Ukrainy pershoi polovyny 19 stolittia [Musical-theatrical life of Ukraine in the first half of the 19th century]. Kyiv muzychnyi, pp.20-31.

6. Ilchenko, L., 1996. Hraf Rozumovskyi [Count Rozumovsky]. Dzerkalo tyzhnia, 38, p.2.

7. Kalenychenko, A., 1990. Kamerno-instrumentalni ansambli. In: O. Parkhomenko, ed. Istoriia ukrainskoi muzyky [History of Ukrainian music]. Kyiv: AN URSR; IMFE im. M. T. Rylskoho, pp.265-286.

8. Kyianovska, L. O., 2000. Stylistic evolution of Galician musical culture of the 19th-20th cent. Ph.D. in Art History. Abstract of Thesis. Tchaikovsky National Academy of Music of Ukraine.

9. Kornii, L., 1998. Istoriia ukrainskoi muzyky [History of Ukrainian Music]. Vol. 2. KyivKharkiv-Niu York: vydavnutstvo M. P. Kots.

10. Kornii, L., 2001. Istoriia ukrainskoi muzyky [History of Ukrainian Music]. Vol. 3. KyivKharkiv-Niu York: vydavnutstvo M. P. Kots.

11. Stupel', A., 1970. V mire kamernoi muzyki [In the world of chamber music]. Leningrad: Muzyka. 
12. Symarokova, V., 2003. Muzychne vykonavstvo yak obiekt doslidzhennia [Musical performance as an object of study]. Mystetski obrii 2001-2002: Almanah. Naukovo-teoretychni pratsi ta publitsystyka, pp.212-222.

13. Feshchak, N., 2011. Salonnist yak faktor rozvytku ukrainskoho kvartetnoho zhanru [Saloniness as a factor in the development of the Ukrainian quartet genre]. Visnyk Derzhavnoi Akademii kerivnykh kadriv kultury i mustetstv, 4, pp.191-194.

14. Shamaieva, K., 1996. Muzychna osvita v Ukraini v pershii polovyni 19 stolittia [Musical Education in Ukraine in the first part of 19th century]. Kyiv: Muzychna Ukraina.

15. Shchepakin, V., 2012. Kamerne vykonavstvo v Odesi naprykintsi 1860-h -pochatku 1870-h rr. yak pryklad tvorchoi vzaemodii predstavnykiv riznych kultur [Chamber performance in Odesa in the End of 1860 s - at the beginning of 1870 s as an example of creative interaction of representatives of different cultures]. Kultura Ukrainy, pp. 276-288.

NATALIIA FESHCHAK ORCID iD: 0000-0001-6543-1985 PhD in Art Criticism, Acting Associate Professor at the Department of String-Bowed Instruments at the P. I. Tchaikovsky National Music Academy of Ukraine (Kyiv, Ukraine) feshchak.natalia@gmail.com

\section{PERFORMANCE PRINCIPLES OF FUNCTIONING OF UKRAINIAN CHAMBER QUARTET: HISTORIC ASPECT}

Peculiarities of string quarter music units were shown from the chamber-instrumental perspective existing in the Ukrainian performing art. As well, these peculiarities were disclosed as a distinct genre of composer's approach and his musical thinking. Consistent development of equal ensemble of four string instruments with their timbres close to human voices happened in the second part of the 18th century. Chamber part of their utterances was directed to the concentration of feelings, reproduction of psychological states. It was mentioned that a very specific form of concert "communication" was spread in the Ukrainian chamber world in the 18th-19th centuries; it is especially about saloon music. Both chamber pieces of Western authors and folklore pieces that are significant for Ukrainian ensemble music of that time were popularized in Ukrainian performing space. Until the end of the 19th century, amateurs in music art started to lose their priority step by step. Instead, the considerable penchant for the professional factor had an epoch-making impact, so taking into account this fact and the historical spreading of chamber concerts particularly the chamber writing style acquired the importance. In the 20th century's Ukraine, a new school of Ukrainian quartet performance was being formed. It was associated with high professionalism, special performance manner. Professional quarter ensembles were generated in Kyiv, Lviv, Odesa, and Kharkiv. They were consisted of the best musicians of that time. The establishment of high music institutions was a big impetus for the development of quartet performance in the 20th century. The discipline "Quarter Class" was included in the music education during this time to train very professional performers. During the years of Ukrainian independence, the development of the local chamber quartet moves in two directions: new professional teams are being established from the graduates of music academies - their performance techniques raise to very high, virtuoso quality. They represent an academic direction. The other tendency is an active becoming of the quartet's genre in saloon performance.

Keywords: Ukrainian string quartet, performance, chamber performance, saloon.

Стаття надійшла до редакиії 13.02.2021 